IBIMA Publishing

Journal of Human Resources Management Research

http://ibimapublishing.com/articles/JHRMR/2018/895618/

Vol. 2018 (2018), Article ID 895618, 20 pages, ISSN : 2166-0018

DOI: $10.5171 / 2018.895618$

Research Article

\title{
Effects of Talent Management Components on the Employee Satisfaction
}

\author{
Erkut Altindağ ${ }^{1}$, Nur Yıldız Çirak ${ }^{2}$ and A.Zafer Acar $^{3}$ \\ 1,2 Beykent University, Beykent University Taksim Campus, Beyoğlu İstanbul, Turkey \\ ${ }^{3}$ T.C. Piri Reis University, T.C. Piri Reis Üniversitesi Deniz Kampüsü \\ Postane Mahallesi, Tuzla, İstanbul, Turkey
}

Correspondence should be addressed to: Erkut Altindağ ; erkutaltindag@beykent.edu.tr

Received date: 22 November 2017; Accepted date: 22 February 2018; Published date: 29 June 2018

Academic Editor: Jennifer Abou Hamad

Copyright (C) 2018. Erkut Altindağ , Nur Yıldız Çirak and A.Zafer Acar. Distributed under Creative Commons CC-BY 4.0

\begin{abstract}
Although talent management is a new concept for increasing employee satisfaction and firm performance, it is rapidly becoming of great value for academics and managers. This study explores talent management components such as leadership techniques, management capabilities, advanced management and systems creation approaches, advanced management techniques, efforts to increase inclusiveness, reward systems, performance appraisal systems, and employee selection criteria. It addresses their effects on modern companies' human resources and considers them as major factors supporting sustainable competitive advantages. Also, it delves into existing literature on the effects of talent management practices, which affect one of the vital pillars of companies: the human factor. To achieve its aims, it employs a 53-question survey with seven sub-categories related to employee satisfaction considering a database of 201 survey results from financial services industry. As a result, it finds that effective talent management practices have important influences on human resources, which is the most critical element in a company's survival. Fair and trustworthy performance appraisal systems and management performance appraisals of employees are key activities for enhancing employee feelings of trust and belonging to a company, as well as employee satisfaction in the financial services industry.
\end{abstract}

Keywords: talent, talent management, employee satisfaction, rewards, performance

Jel Code: M10, J24

Cite this Article as: Erkut Altindağ , Nur Yıldız Çirak and A.Zafer Acar (2018)," Effects of Talent Management romnonente on the Fmnlnvep Saticfartion " Inurnal of Human Recnurrec Manaoement Recearrh Vol 2018 


\section{Introduction}

In the constantly moving modern business environment, competitive enterprises have to adapt themselves to innovations in many fields in order to survive and maintain their development. "Talent Management," which has gradually increased in importance in recent years, can be used to find talented employees by using techniques such as career planning, career development, and training. It can provide a significant and sustainable competitive advantage, creating both operational and strategic advantages for entities (Al Ariss et al., 2014; Cappelli, and Keller, 2014; Collings et al., 2015; Vaiman, et al., 2017). The frequently-used term "talent" can be academically defined as describing the ability of an individual to produce creative solutions, encourage others, and foster success even in the face of time limitations. Throughout the $21^{\text {st }}$ century, talent has increased in strategic importance, and in its importance to entities. Losing talent causes vital problems for entities under both positive and negative economic conditions. In this study, the concept of talent management is analyzed in detail within the scope of its own processes, and the effects of factors that are important to those processes on employee satisfaction are revealed based on an experimental application.

The fundamental components of successful talent management are basic approaches related to the employment of strategic personnel, including human resource applications, performance evaluations, reward systems, training and development, positioning, efforts to become an agent of change, and leadership development and applications. Efficient talent management provides opportunities to increase the added value created by employees by improving workforce productivity (Storey, 1988; Kraiger et al., 1993; Ulrich, 1998; Pynes, 2008). Several areas of research must be pursued in order for talent management to grow to maturity and to gain a firm position in the field of human resource management. To enrich literature on this area of study, empirical research should be carried out that focuses on talent management in public and non-profit organizations, or in small and medium enterprises (Thunnissen et al., 2013).

After top management creates them, talent management strategies, like all other strategies, should be controlled in a manner that is compatible with the general strategy of the entity in question. This should include methods that reveal the competence and talents of leaders who will provide the guidance required for the entity to achieve its targets. Carrying out such strategies should be the responsibility of human resource departments. Efficient performance evaluation and reward applications will provide a sustainable competitive advantage and opportunities for long-term talent management approaches to be applied, creating high employee satisfaction or commitment. They also enable talent management programs to be conducted through an approach that is integrated with the participation of coaching and mentorship applications. Fundamental factors of talent management and development include developing the talents and competencies of employees and managing learning, career management, and performance as a whole. A successful talent management application is not only a means of measuring performance but also provides benefits by increasing the behavioral competence of employees. Getting the right people in pivotal roles at the right time is a key factor in achieving success. In order to add value, human resource management and development efforts must provide clear benefits, in terms of its components, areas of practice, and strategies for capitalizing on employee talents (Gilley et al., 2002; Ashton and Morton,2005; Bhatnagar, 2007).

Research carried out by the McKinsey Consulting Firm has revealed that in 20 years, demand for high-quality human resources will outstrip supply. For that reason, it is necessary to determine true talent by systematically analyzing sources of talent, developing talent profiles, creating a knowledge-, experience-, and talent-grading approach for each system, and providing the appropriate positions for 
the right talents. Furthermore, talent management approaches that include activities such as reintroducing highly talented employees into the entity provide essential benefits for businesses (Lawler, 2000).

This study includes four basic sections, which follow this introduction. In the first, the concepts of talent and talent management are analyzed based on a literature review. In the second, a talent management model is created, for finding and attracting potential employees, positioning them, evaluating and developing talent, pricing, rewarding, and evaluating performance. The processes and operations included within the scope of human resources applications in the financial service sector are analyzed in detail, and fundamental components are revealed. In the third section, employee satisfaction is analyzed at the conceptual and methodological levels. Finally, in the fourth and concluding section, findings and suggestions are presented based on general results and those of the questionnaire. It is worth noting that the scope of the study is limited to the financial services sector. The definition of financial sector contains firms that provide financial services to commercial and retail customers. This sector includes banks, investment funds, insurance companies and real estate in general.

In terms of the process involved in carrying out this study, a literature review and questionnaire preparation practice methods were employed. A primary hypothesis and sub-hypotheses were created, and the relevant literature was reviewed. Talent management and the measurement of how its components affect the dependent variable are also the targets of our research question at the same time. The data obtained through the literature review and questionnaire were analyzed, hypothesis tests were performed, and the study was completed with interpretations and suggestions. The primary research question is to measure how effective the talent management practices are on the employee performance.

Talent and Talent Management
The topic of talent management has gained increasing attention in the last two decades. Both companies and institutions have become interested in the concept (Al Ariss et al., 2014). Entities that hope to survive and maintain their development within the competitive and continually changing modern environment have to adapt themselves to innovations in many fields. These include new technologies, viewpoints, concepts, and environmental factors. Talent management is a recent, practitioner-generated term covering a range of long-standing practices that aim at getting the right person in the right job at the right time (Capelli and Keller, 2014). Recently, the growing importance of talent management has become increasingly relevant. Entities that can find talented employees, attract new talents, and provide important human resource opportunities, such as career planning, career development, and training, can obtain significant competitive advantages and create both operational and strategic differences (Doğan and Demiral, 2008). Collings and Mellahi (2009) define strategic talent management as all activities and processes that involve the systematic identification of key positions that differentially contribute to a company's sustainable competitive advantage, the development of a talent pool of highpotential and high-performing incumbents to fill suitable roles, and the implementation of a diversified human resource architecture that facilitates filling these positions with competent incumbents and ensuring their continued commitment to the company. Existing management literature can best be described in terms of three research streams (Tarique and Schuler, 2010), which are as follows:

- Talent management is conceptualized in terms of typical human resource department practices and functions.

- Talent management is defined regarding human resource planning and employee need projection.

- Talent management is treated as a generic approach that either focuses on highperforming and high-potential talent or talent in general. 
Changes in environmental factors have obliged entities to carry out restructuring studies (Erdemir, 2006, 30). Modern human resource management has enabled the determination of managers' competencies, as well as their training and development in a manner that shapes the future of an entity, guiding and supporting the career planning and development of employees in addition to classic personnel management applications (Özgen et al., $2005,7)$. The term "talent" is frequently used in daily life, and has become a valuable aspect of the business. It refers to individuals' competence in producing creative solutions that result in success and motivate others around them (Altuntuğ, 2009, 449). Talent can be evaluated in terms of compositional features such as success, ability, leadership, practicability, creativity, and time. Quality-based definitions of "talent" regard it as practical, iterative, ideational, behavioral, and emotional patterns that can cause productivity in humans. Under this understanding, talent is regarded as innate and implicit (Polat, 2011, 28). Paul Sparta has suggested that talent management systems can be solutions for addressing modern human resource management requirements (as cited by Little, 2006, 24). Talent management can be summarized as an approach for determining employee talents, successfully developing them, and strengthening career paths through support (Yavan, 2012, 77). It is one of the factors supporting the success of an entity. In the $21^{\text {st }}$ century, talent has taken on strategic significance for entities (Yavan, 2012, 77), which has led to what Charles Fishman describes as a "talent war" (As cited in Mucha, 2004, 96). Evaluating human resources as a fundamental factor in success and competitive advantage through a talent management approach provides opportunities for entities to be agile, innovative, and creative (Murphy et al., 2005). Although entities can gain shortterm competitive advantages and profits through resources such as relatively easyto-access financial capital and easily imitable new technologies, talent management provides entities with longterm competitive advantages (Gardner, 2002, 228). Even when entities develop through negative dynamics, protecting talent is essential (Heinen and O'Neill, 2004, 72). Because developing talent means fostering the talents and competencies of employees, it is fundamental to manage learning, career development, and performance within an entity as a whole (Little, 2006, 25). Business continuity is one of the main targets of effective talent management (Yavan, 2012, 81). The process above of evolution is presented in the table below.

Table1: Evolution of Talent Management

\begin{tabular}{|l|l|l|l|}
\hline Size & Innovation Planning & $\begin{array}{l}\text { Achievement } \\
\text { Planning }\end{array}$ & Talent Management \\
\hline Purpose & Risk management & $\begin{array}{l}\text { Strategic personnel } \\
\text { and development }\end{array}$ & $\begin{array}{l}\text { Broad source and } \\
\text { development }\end{array}$ \\
\hline Target & $\begin{array}{l}\text { Key administrative } \\
\text { duties }\end{array}$ & $\begin{array}{l}\text { Working group with } \\
\text { high potential }\end{array}$ & $\begin{array}{l}\text { Broad organizational } \\
\text { innovation }\end{array}$ \\
\hline Evaluation & $\begin{array}{l}\text { Private business } \\
\text { potential and } \\
\text { performance }\end{array}$ & $\begin{array}{l}\text { Performance trends } \\
\text { and leadership in } \\
\text { competition }\end{array}$ & $\begin{array}{l}\text { All talent and result- } \\
\text { based }\end{array}$ \\
\hline Career Path & $\begin{array}{l}\text { Below functions as } \\
\text { linear and fact }\end{array}$ & $\begin{array}{l}\text { Cross functions, some } \\
\text { geographical and } \\
\text { regional acts }\end{array}$ & $\begin{array}{l}\text { Opportunist and cross } \\
\text { functions, in terms of } \\
\text { geography and work }\end{array}$ \\
\hline Application & Annual investigations & $\begin{array}{l}\text { Annual investigations } \\
\text { including development } \\
\text { plans }\end{array}$ & $\begin{array}{l}\text { Ongoing activities } \\
\text { organized according to } \\
\text { human resource } \\
\text { processes }\end{array}$ \\
\hline Ownership & Executives & Partners & Shared; employees, \\
\hline
\end{tabular}




\begin{tabular}{|l|l|l|l|}
\hline & & & $\begin{array}{l}\text { personnel experts, } \\
\text { leaders, and CE0 }\end{array}$ \\
\hline Participation & Compulsory & $\begin{array}{l}\text { Depends upon } \\
\text { acceptance }\end{array}$ & Based on interest \\
\hline
\end{tabular}

Reference: Farley, C. (2005),"HR's role in talent management and driving business results", Employment Relations Today, Vol. 32, No. 1, pp. 55-61.

As argued in recent studies, a key limitation of extant work on talent management has been the limited consideration of the measures of success (Collings, 2014). Just as employees of an organization may not be aware of the experiences of their institution, some organizations are not aware of the talents of their employees. The discipline of human resource management covers strategy formulation, and the planning, organizing, managing, and supervising of activities related to finding, positioning, and developing human resources and creating competitive advantages in institutions (Yüksel, 2004, 341). Organizational culture and organizational sociology are the two leading areas of recent human resource analysis efforts. Organizational analysis may address visible or invisible factors. Factors such as symbols, behavioral models, and intra-organizational power relations make up the invisible aspect of organizational analysis (Pfeffer, 1981, 152). Symbols can be presented to candidates by human resource managers during the personnel selection and positioning process (Dandridge et al., 1980, 77). These affect the image of an institution over the long term, as well as the factors above (Doğan and Demiral, 2008, 146). Comprehensive programs addressing leadership potential, performance evaluation, the creation of development activities, and work experience are essential to the success of talent management applications (Cohen, 2001, 52). In assigning superior talents with entities, it is essential that talent management approaches consider the possibility of an individual's performance surpassing his or her team's performance.
In such cases, it is important to recognize talented employees within the institution to prevent the employee turnover rate from increasing. When the job satisfaction of employees decreases, training and talent development efforts will be ignored and elitist organizational culture will emerge (Yavan, 2012, 81). The efficient management of talent includes addressing the ultimate benefits that can be provided by employees with different talents (Doğan and Demiral, 2008, 149). According to Lewis and Heckman (2006), talent management definitions can be grouped into three groups: output, process, and input. These can be grouped as follows (Polat, 2011, 29):

Output: Talent management is focused on keeping adequately qualified employees available for disposal at the most appropriate time and place.

Process: Talent management includes structural and detailed studies aimed at maintaining leadership in key positions.

Input: Talent management provides a flow of talent within a supply and demand framework.

Studies of human resources have revealed that entity characteristics such as content, size, and strategy can direct decisions on employment applications (Olian and Rynes, 1984, 170). These findings indicate that entities need to have structures for addressing employment applications that facilitate the harmonizing of candidates' talents and behaviors with entity strategy for the future (Schneider, 1983). 
Table2: Correct and Incorrect Regulation in Talent Management

\begin{tabular}{|l|l|}
\hline $\begin{array}{l}\text { Misregulated Talent Management } \\
\text { Applications }\end{array}$ & $\begin{array}{l}\text { Talent Management Prepared According to } \\
\text { Strategy }\end{array}$ \\
\hline $\begin{array}{l}\text { Delays and misregulations in talents of } \\
\text { employees according to market demand. }\end{array}$ & $\begin{array}{l}\text { Appropriate allotment of workforce talents, } \\
\text { behavioral subsidiaries, and strengthened } \\
\text { business strategies. }\end{array}$ \\
\hline $\begin{array}{l}\text { Limited responsibility and clear visibility of } \\
\text { business plans. }\end{array}$ & $\begin{array}{l}\text { Individual expectations and performance } \\
\text { targets reorganized according to } \\
\text { organizational value and priorities. }\end{array}$ \\
\hline $\begin{array}{l}\text { Deficiencies in a career path or competitive } \\
\text { and limited career options prevent retention } \\
\text { of individuals with superior ability. }\end{array}$ & $\begin{array}{l}\text { Work success and workforce diversification } \\
\text { are supported by functional career path } \\
\text { architecture. }\end{array}$ \\
\hline $\begin{array}{l}\text { Contrasts in instruments and processes } \\
\text { cause problems with disorganization, } \\
\text { misevaluation, and wrong development of } \\
\text { messages related to the determination. }\end{array}$ & $\begin{array}{l}\text { Talent management program helps } \\
\text { harmonious creation of organization outputs. }\end{array}$ \\
\hline
\end{tabular}

Heinen, J., O'neill, C. (2004), "Managing Talent To Maximize Performance", Employment Relations Today, Volume: 31, No: 2.

Minbaeva and Collings (2013) have addressed seven myths of global talent management and provided the following process suggestions:

- Analyze the fit between global talent management as a strategic business process and human resource management architecture.

- Investigate how human resources systems within a differentiated architecture affect the human capital attributes needed for strategic positions.

- Examine the human capital attributes needed for strategic positions and their effects on behavior.

- Analyze the aggregation of individual behaviors for effective GTM implementation at the group and organizational levels.

The mutual relationships of talent strategies and entity strategies presented in Table 2 clearly reveal how a successful talent management process is related to required entity strategy planning processes. Each entity should create specific talent management strategies that are shaped by both entity and human resource strategy. All changes in entity strategy create a need to re-evaluate talent management strategies. Although management talents and talents owned by an entity are directed toward the same strategic target, they cause the creation of different performance and productivity levels in entities (Heinen and 0'Neill, 2004, 71). Mellahi and Collings (2010) note that in developing the field of global talent management a key issue for academics is to differentiate between global talent management and international human resource management. Sparrow et al. (2013) have found that global talent management strategy is highly embedded in broader business structures and in shifts in the direction of globalization within a sector, which entails epochs and episodes of internationalization.

Finally, the last issue that needs to be addressed is personal selection criteria. Aksakal et al. (2013) mentioned that Talent management is defined as an outcome to ensure the right person is in the right job; process to ensure leadership continuity in key positions and encourage individual advancement. The main decision is to manage sourcing and attracting and flow of talent through the human capital engine. 


\section{The Concept of Employee Satisfaction}

Job satisfaction is a concept that is hard to define and qualify. The concept primarily came into use in the 1920s. In the 1930s and 1940s, understanding of the importance of job satisfaction increased, and it came to be accepted that the attitudes of employees towards their professions affected the quality of their work (Çabukel, 2008, 3). The concept of employee satisfaction can be defined in terms of a scale of satisfaction, and is reflected in the positive attitudes of employees toward jobs. Other important factors in employee satisfaction include the level to which employee expectations are met and to which they enjoy material and spiritual benefits (Erken, 2013, 2). Employees' satisfaction and pleasure regarding their jobs and work environment salso define job and employee satisfaction (Pekdemir et al., 2006, 16). Satisfaction describes the harmony between individual needs and institutional expectations (Yıldız, 2003, 5). In other words, employee satisfaction is created at the point when both the material and emotional expectations of employees are by their actualization (Çabukel, 2008, 3). Sims and Kroeck (1994) argue that when individual characteristics and organizational characteristics are similar, employee satisfaction may be high. The term "employee engagement" refers to an individual's involvement and satisfaction with work, as well as enthusiasm for it (Harter et al., 2002). Meanwhile, employee satisfaction can be seen in terms of the maximum benefit that employees try to obtain from their managers, colleagues, and work itself (Şimşek, 1998, 160). If employee expectations are in harmony with the work that they perform, employee satisfaction occurs (Eren, 1996, 112). This is referred to as "person-organization fit." In order to decrease and eliminate employee dissatisfaction, as the negative equivalent of employee satisfaction, it is necessary to evaluate employees as talents and regard them as a source of competitive advantage for the entity (Barutçugil, 2002, 169).
In a study they carried out in 1975, Hackman and Oldman revealed that five fundamental features should be permanent in entities in order to increase employee satisfaction. Those features are: workrelated talent variations that should be owned, identification with work, the essence of work, freedom allowed to employees, and feedback related to performance (Telman and Ünsal, 2004, 27). In an empirical study, Madlock (2008) has found that task and relational leadership style are positively related to job satisfaction. Employee satisfaction, as a dynamic factor, has a direct effect on employee performance (Erken, 2013, 3).

Wangenheim et al. (2007) point out that customer satisfaction depends on the satisfaction of employees. Pettit et al. (1997) prove that there is a strong relationship between job satisfaction and job performance. A study by Chi and Gursoy (2009) also suggests that employee satisfaction is one of the significant determinants of customer satisfaction, and that employee satisfaction indirectly influences financial performance.

\section{Methodology}

This study questions and examines the effects of leadership application techniques, comprehensiveness, talent management, advanced management and system creation techniques, rewarding and performance evaluation techniques, and personnel selection criteria. It evaluates these within the scope of talent management, and in terms of the working performance of employees. A questionnaire was used as the preferred research method for the study. The questionnaire form prepared for the research included 53 items, as well as questions on demographical features. A seven-point Likert-type scale was used for all of the questionnaire items, except for nine questions related to determining demographical features. We ensured that all items were simple and understandable in terms of language and usage. Items are measured on a seven point Likert-type scale ranging between 1 (strongly 
disagree) and 7 (strongly agree). A control questionnaire was correctly understood. question was also added to ensure that the

Table3: Factorial Components and Numbers of Asked Questions

\begin{tabular}{|l|c|}
\hline Factor Groups & Number of Questions \\
\hline Leadership Application Techniques & 3 \\
\hline Comprehensiveness & 3 \\
\hline Management Talent & 5 \\
\hline Advanced Management and System Creation Techniques & 6 \\
\hline Rewarding and Performance Evaluation Techniques & 20 \\
\hline High Level Management Talent & 6 \\
\hline Personnel Selection Criteria & 10 \\
\hline Total Number of Questions & $\mathbf{5 3}$ \\
\hline
\end{tabular}

The questionnaire form basically included two sections. The first of these was used to determine the demographical features of employees. In the second section, questions were measuring the effects on employee performance of leadership application techniques, comprehensiveness, talent management, advanced management and system creation techniques, rewarding and performance evaluation techniques, and personnel selection criteria which are composed from existing literature. The study population included employees of independent investment companies in the finance sector in Turkey. A total of 201 people participated in the questionnaire.

Table 4: Descriptive Statistics of the Sample

\begin{tabular}{|l|c|c|}
\hline Gender & Number & Percentage \\
\hline Male & 86 & 43 \\
\hline Female & 115 & 57 \\
\hline Total & 201 & 100 \\
\hline Education & Number & Percentage \\
\hline High School & 6 & 3 \\
\hline Undergraduate & 16 & 8 \\
\hline Graduate & 137 & 68 \\
\hline Master's / PhD & 42 & 21 \\
\hline Status & Number & Percentage \\
\hline Top Level Manager/ Owner & 8 & 4 \\
\hline Middle Level Manager & 76 & 38 \\
\hline Bottom Level Manager & 117 & 58 \\
\hline Total & 201 & 100 \\
\hline Tenure & Number & Percentage \\
\hline 1-5Years & 121 & 60 \\
\hline 6-10 Years & 44 & 22 \\
\hline 11-20 Years & 26 & 13 \\
\hline 20+ Years & 10 & 5 \\
\hline
\end{tabular}


The technical assumptions made for the research are as follows:

Main Hypothesis $\left(\mathrm{H}_{M}\right)$ : Talent

management components have a direct and positive effect on employee satisfaction.

$\mathbf{H}_{1}$ : There is a positive relationship between high-level management talent and employee satisfaction.

$\mathbf{H}_{2}$ : There is a positive relationship between advanced management and system creation techniques and employee satisfaction.

$\mathbf{H}_{3}$ : There is a positive relationship between the comprehensiveness of techniques and employee satisfaction.

H4: There is a positive relationship between management talent and employee satisfaction.

H5: There is a positive relationship between rewarding and performance evaluation techniques and employee satisfaction.
H6: There is a positive relationship between personnel selection criteria and employee satisfaction.

H$_{7}$ : There is a positive relationship between leadership application techniques and employee satisfaction.

Based on the data obtained through the questionnaires, reliability analyses and validity analyses were performed. This was followed by factor analysis, correlation analysis, and regression analysis, which aimed to analyze the relationships between factors. Cronbach's Alpha $(\alpha)$ values were analyzed to evaluate measurements, and their reliabilities were also tested. The values obtained that were above 0.70 were considered to be significant. When corrected inter-item correlation coefficients were analyzed, they were controlled, whether all values were above 0.500 or not. When alpha values were analyzed, it was determined that their values were above the value of 0.700 accepted in the literature, even when no variable was excluded (Allen and Yen, 2002).

Table 5: Reliability statistics

\begin{tabular}{|c|c|}
\hline Variable Name & Cronbach's Alpha \\
\hline Leadership &, 887 \\
\hline Comprehensiveness &, 861 \\
\hline Management Talent &, 947 \\
\hline Advanced Management and System &, 954 \\
\hline $\begin{array}{c}\text { Employee satisfaction / Reward and } \\
\text { Performance }\end{array}$ &, 970 \\
\hline High Level Management Talent &, 980 \\
\hline Personnel Selection &, 915 \\
\hline
\end{tabular}

In terms of reliability, when the results obtained within the scope of the analysis were analyzed, as shown in Table 5 , it was determined that there was no variable with a value below 0.700 , which is accepted as the threshold value for reliability (Cronbach, 1951). A factor analysis was then performed to determine whether the scale was single or multifactorial. The research model was tested by using correlation and regression analysis techniques, according to the mutual interaction analysis results. Correlation analysis was carried out first to analyze the relationship between random variables (factors), indicating the level of divergence from independence in general statistical use. According to the analyzed situation, different correlation coefficients were developed. The most frequently-known and 
used of all of these coefficients is the Pearson product-moment correlation coefficient. It is calculated through the division of two variables' covariance into the multiplication of those variables' standard deviations (Türkbal, 1981; Hair et al. 2006). The correlation coefficient describes the size and direction of the relationship between variables. This coefficient has a value ranging between (1) and (+1). Positive values represent a direct linear relationship and negative values represent a reverse linear relationship. If this coefficient has a value of (0), it proves that there is no linear relationship between the variables included in the research. 
Table 6: Results of Correlation Analysis

\begin{tabular}{|c|c|c|c|c|c|c|c|c|c|c|c|}
\hline & $\sum^{000}$ & ผิ & - & N & $m$ & + & in & $\bullet$ & N & $\infty$ & $a$ \\
\hline (1) Leadership & 49.619 & 148.817 & 1 & & & & & & & & \\
\hline (2) Comprehensiveness & 50.647 & 142.545 & $.791^{* *}$ & 1 & & & & & & & \\
\hline (3) Management talent & 48.269 & 150.993 & $.816^{* *}$ & $.838^{* *}$ & 1 & & & & & & \\
\hline $\begin{array}{l}\text { (4) Advanced management and } \\
\text { system }\end{array}$ & 46.799 & 146.661 & $.721^{* *}$ & $.713^{* *}$ & $.857^{* *}$ & 1 & & & & & \\
\hline (5) Employee satisfaction & 43.951 & 149.747 & $.681^{* *}$ & $.645^{* *}$ & $.797^{* *}$ & $.830^{* *}$ & 1 & & & & \\
\hline (6) Reward and performance & 54.444 & 112.674 & $.569^{* *}$ & $.593^{* *}$ & $.666^{* *}$ & $.671^{* *}$ & $.697^{* *}$ & 1 & & & \\
\hline (7) High level management & 47.015 & 152.958 & $.667^{* *}$ & $.657^{* *}$ & $.760^{* *}$ & $.794^{* *}$ & $.837^{* *}$ & $.655^{* *}$ & 1 & & \\
\hline (8) Personnel selection 1 & 55.224 & 111.801 & $.375^{* *}$ & $.392^{* *}$ & $.464^{* *}$ & $.557^{* *}$ & $.508^{* *}$ & $.443^{* *}$ & $.582^{* *}$ & 1 & \\
\hline (9) Personnel selection2 & 55.005 & 110.564 & $.355^{* *}$ & $.413^{* *}$ & $.468^{* *}$ & $.553^{* *}$ & $.463^{* *}$ & $.399^{* *}$ & $.509^{* *}$ & $.739^{* *}$ & 1 \\
\hline
\end{tabular}


The most interesting finding in this regard is that high levels of management talent have a very high correlation effect on the fairness and objectivity of performance systems. Managers with high levels of leadership talent, who create a common vision for employees, make strategic plans, and effectively engage in interior and exterior communication tend to increase employee satisfaction and positively affect the fairness and objectivity of the performance system of an entity. Applying a transparent and productive model to the dependent variable also proved that a close relationship existed between the two variables, indicated by their high rate of interaction. In other words, high levels of administrative talent among managers were connected to high levels of interaction between the variables addressed in this research. This finding proves that the employment of highly-talented managers, based on their talent and potential for success, has a positive effect on employee satisfaction. The level of this effect, and the cause-result relationship involved, were more comprehensively explained by a regression analysis carried out in the subsequent stage of this research.

According to the findings of this study, reward and performance systems, and employee satisfaction based on them, are affected by advanced management and system creation applications used in an entity. When senior managers provide feedback to employees, eliminate structural obstacles, and show their trust of employees, it is correlated with fair and objective performance systems and transparent and productive management models. This research also found that personnel selection criteria were correlated at a medium level with both dependent variables. The basic reason for this is that employees can understand fair and objective performance systems. For this reason, personnel selection criteria had a lower correlation level than other independent variables. Another prominent point of this statistical analysis was that management talent in institutions affected both dependent variables and employee satisfaction. Department managers should give feedback to their employees related to performance, and enable employees to discover the concept of trust. This allows everybody affiliated with those managers to understand that their performances have been evaluated objectively and fairly, and that they have enough resources and support to carry out their best possible work. This, in turn, will increase managerial talent and performance.

Finally, this study found that leadership applications and techniques to ensure comprehensiveness were correlated with the two dependent variables of this research. The fact that almost all independent variables are significant in one-to-one relationships is proof that the theoretical sub-structure of the research model was strongly established and that the selected scales were appropriate.

In the subsequent stage of research, all cause-result relationships were analyzed using a regression model, which revealed all of the causal relationships within the model. On an objective level, it may be impossible for the independent variables in this study to affect the dependent variables. In order to arrive at more specific findings, the regression model was used. Regression analysis is a method used to measure the relationship between two or more variables. The analysis that considers only one variable is called regression analysis, while analysis using more variables is called multi-variable regression analysis. Through this analysis method, the relationship between variables is revealed, and the extent of their relationship can also be assessed. One crucial point that should be considered in performing regression analysis is that while the method reveals the changes of two variables together, it should also provide information related to cause-result relationships between these variables (Nakip, 2003,290).

\footnotetext{
All models on which regression analysis was performed were analyzed with the SPSS17 application. The models and their results are described in more detail in the subsequent sections. The specificity coefficient was expressed with $R^{2}$ value in the tables below. The criteria indicating the statistical significance of the created models are indicated by " $F$ " in the tables.
} 
Table 7: Effects of Talent Management Components on Employee Satisfaction

\begin{tabular}{|c|c|c|c|c|c|}
\hline \multirow[t]{2}{*}{ Model } & \multicolumn{2}{|c|}{$\begin{array}{c}\text { Non-Standardized } \\
\text { Coefficients }\end{array}$} & \multirow{2}{*}{$\begin{array}{c}\begin{array}{c}\text { Standardized } \\
\text { Coefficients }\end{array} \\
\text { Beta }\end{array}$} & \multirow[b]{2}{*}{$\boldsymbol{t}$} & \multirow[b]{2}{*}{$p$} \\
\hline & $B$ & $\begin{array}{c}\text { Std. } \\
\text { Deviation }\end{array}$ & & & \\
\hline (Constant) & .048 & .194 & & .248 & .804 \\
\hline Leadership & .047 & .062 & .047 & .766 & .445 \\
\hline Comprehensiveness & -.125 & .068 & -.119 & -1.846 & .066 \\
\hline Management skill & .253 & .086 & .255 & 2.923 & .004 \\
\hline $\begin{array}{l}\text { Advanced management } \\
\text { and system }\end{array}$ & .316 & .072 & .310 & 4.368 & .000 \\
\hline High level management & .435 & .055 & .445 & 7.872 & .000 \\
\hline$R^{2}: 78$ & $: 782$ & $2.558 \mathrm{~S}$ & Error of & ate:.6 & \\
\hline
\end{tabular}

Dependent Variable: Employee Satisfaction

Some striking results were obtained in the multiple causality (regression) analysis that was performed subsequent to the correlation analysis. The first analysis aimed to determine the effects of five different variables (leadership, comprehensiveness, management talent, advanced management and system creation techniques, and high-level management talents) on employee satisfaction as the dependent variable. The obtained findings proved that the factors of leadership and comprehensiveness were shaded by the other three factors. In other words, when high-level management talents were employed and their talents in their fields were applied, the leadership qualifications and work comprehensiveness of entities became less important. In summary, some variables that were shown to be in a situation of mutual interaction in correlation analysis were found to become inefficient in regression analysis. The beta values of independent variables that were found to be insignificant varied between 0.255 and 0.455. The rate at which the aforementioned variables explain the dependent variable related to employee satisfaction was $78.7 \%$.

Table 8: Effects of Talent Management Components on Performance and Reward System

\begin{tabular}{|c|c|c|c|c|c|c|}
\hline \multirow{2}{*}{\multicolumn{2}{|c|}{ Model }} & \multicolumn{2}{|c|}{$\begin{array}{c}\text { Non-Standardized } \\
\text { Coefficients }\end{array}$} & \multirow{2}{*}{$\begin{array}{c}\begin{array}{c}\text { Standardized } \\
\text { Coefficients }\end{array} \\
\text { Beta }\end{array}$} & \multirow[b]{2}{*}{$t$} & \multirow[b]{2}{*}{$p$} \\
\hline & & $\boldsymbol{B}$ & $\begin{array}{c}\text { Std. } \\
\text { Deviation }\end{array}$ & & & \\
\hline \multirow[t]{6}{*}{1} & (Constant) & 2.635 & .221 & & 11.924 & .000 \\
\hline & Leadership & -.009 & .070 & -.012 & -.130 & .896 \\
\hline & Extensiveness & .084 & .077 & .107 & 1.090 & .277 \\
\hline & Management skill & .135 & .099 & .181 & 1.369 & .173 \\
\hline & $\begin{array}{l}\text { Advanced management } \\
\text { and system }\end{array}$ & .180 & .083 & .234 & 2.173 & .031 \\
\hline & High level management & .199 & .063 & .270 & 3.153 & .002 \\
\hline
\end{tabular}

Dependent Variable: Performance and Reward System

Table 8 presents regression results indicating whether the factors of rewarding and performance, as dependent variables, were affected by five independent 
variables. In this analysis, the most interesting finding was that management talent, as an independent variable that was found to be significant in the previous analysis, lost its efficiency. Moreover, advanced management and system creation techniques affected the dependent variable at a $51.1 \%$ rate, and at the $1 \%$ level of significance. In particular, managers' high levels of leadership talent, their creation of vision, their ability to engage in strategic planning, and their high communication levels directly affected employee performance. This supported the idea that the fairness of the reward and performance system affects employee satisfaction, which is a widely accepted opinion in existing literature. In the conclusion section of this paper, various evaluations of talent management for academics and managers are made, and some suggestions are offered.

Table 9: Research Hypotheses Acceptance Table

\begin{tabular}{|l|c|c|}
\hline \multicolumn{1}{|c|}{ Independent Variables } & \multicolumn{2}{c|}{ Employee Performance } \\
\cline { 2 - 3 } & Hypothesis & Supported \\
\hline High Level Management Skills & $\mathrm{H}_{1}$ & \\
\hline $\begin{array}{l}\text { Techniques for Advanced Management and System } \\
\text { Development }\end{array}$ & $\mathrm{H}_{2}$ & Supported \\
\hline Extensiveness & & Not supported \\
\hline Management Skill & $\mathrm{H}_{3}$ & Supported \\
\hline $\begin{array}{l}\text { Leadership } \\
\text { Talent Management Components Have Direct and } \\
\text { Positive Effect on Employee Satisfaction }\end{array}$ & $\mathrm{H}_{4}$ & Not supported \\
\hline
\end{tabular}

\section{Additional Findings}

Within the scope of the research, reliability, validity, factor, correlation, and regression analyses were performed. Because the content of the employed questionnaire was comprehensive, some additional analyses could be performed by using the SPSS17 program. The average, median, mode, standard deviation, minimum, and maximum values of the scale, including 10 questions related to personnel selection criteria, were a particular focus of analysis. The most important points of the related analyses were that the language knowledge of individuals with ethical behaviors, as indicated in the fifth and $10^{\text {th }}$ questions, had much higher standard deviation values than those indicated by the other questions. The fifth question had a 1.50 standard deviation ratio, while the $10^{\text {th }}$ question had a 1.53 standard deviation ratio. The high standard deviation ratios of these questions proved that they were responded to at a very wide response interval by both employees and managers. The especially high standard deviation value for the questions related to the importance of ethical values could mean that managers pay particular attention to this factor during the employment period. The question with the lowest standard deviation was the fourth, concerning the professional training of individuals. This result indicated that the most important indicator during the employment period was professional training. In other words, one important factor in the selection of 
employee candidates is their professional training and specialization. This was especially the case in Turkey, where the most important point for managers working in their family businesses was individuals' talents for carrying out work. Because professional training and professional expertise are correlated, this additional finding revealed by the research was not theoretically or practically surprising. Furthermore, the differentiation of the importance of ethical behaviors among managers is a comprehensive research item that should be emphasized.

Table 10: Personnel Selection Criteria

\begin{tabular}{|l|c|c|c|c|c|c|c|}
\hline $\boldsymbol{N}$ & Valid & Average & Median & Mode & $\begin{array}{l}\text { Std. } \\
\text { Deviation }\end{array}$ & Min. & Max. \\
\hline Appearance & 201 & 5.4129 & 6 & 6 & 1.38695 & 1 & 7 \\
\hline Oratory & 201 & 5.6866 & 6 & 6 & 1.32146 & 1 & 7 \\
\hline Attribute & 201 & 5.6219 & 6 & 6 & 1.28309 & 1 & 7 \\
\hline Profession & 201 & 5.7313 & 6 & 6 & 1.17365 & 1 & 7 \\
\hline Language & 201 & 5.1592 & 5 & $5.00^{a}$ & 1.50151 & 1 & 7 \\
\hline References & 201 & 5.4179 & 6 & 6 & 1.41932 & 1 & 7 \\
\hline Wage Demand & 201 & 5.4428 & 6 & 6 & 1.31071 & 1 & 7 \\
\hline Health & 201 & 5.5323 & 6 & 6 & 1.31537 & 1 & 7 \\
\hline Previous Job & 201 & 5.3234 & 6 & 6 & 1.47645 & 1 & 7 \\
\hline Ethics & 201 & 5.7861 & 6 & 7 & 1.52938 & 1 & 7 \\
\hline
\end{tabular}

Multiple modes were found. The minimum mode value is marked in the table.

It can be considered a normal result that professional expert knowledge is important in the finance sector. However, the finding that the coherence of ethical principles is not adequately evaluated in personnel selection in the trust-based sector was unexpected.

\section{Conclusion}

This study aimed to analyze the effect of talent management components within the finance sector on employee satisfaction. Talent management is important for largesized enterprises as well as SMEs (small and medium-sized enterprises). It has been evaluated as an essential contemporary topic, and important studies on the subject are regularly carried out. In this experimental study, leadership, comprehensiveness, management talent, advanced management and system creation techniques, and high-level management skills were used as independent variables. The talent management approach was established based on the idea of benefiting from the performance of talented employees, and supporting them as the strategic leaders of the future by providing appropriate environments. This study determined that a fair and reliable performance system increases employees' feeling of trust and belonging, and that when managers provide feedback to employees, it positively affects employee satisfaction. The application of the model in this research also provided some other important findings, which are described below.

If all of the firms giving importance to talent management use a fair and reliable performance system, their employees increase their positive feelings toward their firms and become more faithful. For 
that reason, determining management talents and employing individuals in jobs that are appropriate to their expertise positively affects organizational citizenship. If the visions and missions of entities have been determined and job descriptions are clear, the satisfaction of employees with performance evaluation systems will increase. Moreover, when department managers eliminate all unnecessary obstacles related to jobs and regularly provide feedback, employees will perform their best. When senior managers provide structural feedback related to employees working for them and keep the existing values of their organizations alive, it increases employee satisfaction.

Unexpectedly, the evaluations carried out for this study did not prove that managers' leadership talent had a positive effect on employee performance in the financial services sector. Although a significant effect was found in the correlation analysis, it was shaded in the multiple regression model. Department managers' constant cooperation with employees is not a factor that has an effect on its own. Because top managers' ability to engage in strategic planning and training directly affect employee performance and satisfaction, these can be practiced as institutional policy by top management, which will strengthen their companies' core competitive strategy. When a system is created that is appropriate to the talents of managers, employees know the positions that they can be promoted to, believe that performance and reward systems are fair and correct, and develop organizational commitment toward their companies. This can present a great competitive advantage for the organization in question, which goes beyond financial benefits. This study also determined that personnel selection criteria do not have a strong effect on employee satisfaction. The reason for this low-level effect was that employees saw the performance and reward system as correct. This is because when private and senior-level managers appropriately allot employment to candidates, it allows them to achieve their potential for success, and doing so contributes positively to employee satisfaction. A similarly unexpected result was found with regard to job comprehensiveness. The relationship between job comprehensiveness and employee performance shown in the correlation analysis could not be proved through multiple regression analysis.

In order to determine to what extent the dependent variables of fair and objective performance systems and transparent and productive management model applications were affected by the other independent variables, a correlation analysis was performed subsequent to the factor analysis. The most interesting of the correlation analysis results concerned the high-level positive effect of management talent on dependent variables. This suggests that coherent and efficient performance systems naturally exist in entities with high levels of management talent, which positively affects employee satisfaction.

Furthermore, the results of the correlation analysis revealed that advanced management and system creation techniques and reward and performance systems were correlated with each other at an above-average level. Multiple regression analyses showed that while advanced management techniques had a strong effect on the first sub-factor of rewarding and performance, as the first dependent variable (0.310), this effect decreased for the second sub-factor variable of rewarding and performance as the second dependent variable (0.234). The significance of all oneto-one relationships in correlation analysis indicated that the research model was theoretically strong, and that the correct scales were used. Some striking results were obtained in the subsequent multiple causality analysis, which revealed some cause-result relationships and variables. Basically, three independent variables were found to affect employee satisfaction as the first dependent variable, and these explained $78.7 \%$ of the dependent variable. These independent variables were management talent, advanced management and system creation techniques, and highlevel management talent. It was also noticed that leadership and comprehensiveness factors, as the other 
independent variables, were shaded by these three factors. The most attentiongrabbing result for rewarding and performance, as the second dependent subfactor variable, was that the effect of the independent variable of management talent decreased. Moreover, it affected the dependent variable by $51.1 \%$ at the $1 \%$ level of significance, together with advanced management and system creation techniques. To ensure that the reliability and validity of research results were high, the number of samples was set above a specific level. However, because the financial sector is inflexible in terms of confidential information, and is closed in nature, it took more time than expected to reach the target level of participation.

In addition, in order to distribute the questionnaires more easily, and gain responses in a shorter time, the drive.google.com website was employed to provide a technological advantage. However, because the finance sector has high security standards due to the critical nature of security, participants could not complete questionnaires within their working environments, which created the necessity of using personal Internet connections. This security limitation was an additional factor that extended the questionnaire participation period. Despite the aforementioned issues, this experimental study makes important contributions to existing scientific literature. Importantly, it suggests that academics quantitatively increase their sample groups and, if possible, carry out research with international companies. According to the findings obtained from correlation and regression analyses, a systematic structure that can reveal the talents of employees, and especially managers, increases employee satisfaction and employee performance.

Future studies based on these research results should make the findings of this study more generalizable, and help to reveal the effects of other components of talent management on employee performance. These obtained additional relationships can be used as a guide for increasing the efficiency of talent management applications in entities. Ethical values' lack of inclusion in personnel selection criteria should also be discussed in more detail. Exploring the findings in a greater level of detail would also be relevant to the finance sector, particularly with regard to principles of trust and ethics.

\section{References}

1. Aksakal, E., Dağdeviren, M., Eraslan, E. and Yüksel, İ. (2013). Personel selection based on talent management. ProcediaSocial and Behavioral Sciences, 73, 68-72.

2. Allen, M. J. and Yen, W. M. (2002), Introduction To Measurement Theory, Long Grove, Il: Waveland Press.

3. Al Ariss, A., Cascio, W. F. and Paauwe, J. (2014). Talent management: Current theories and future research directions. Journal of World Business, 49(2), 173-179.

4. Altuntuğ, N. (2009), "Rekabet Üstünlüğünün Sürdürülmesinde Yeteneklerin Rolü: Yetenek Yönetim Yaklaşımı" (Sustainable Competitive Advantage In The Role Of Talent: Talent Management Approach), Süleyman Demirel Üniversitesi İktisadi Ve İdari Bilimler Fakültesi Dergisi, C. 14, 3, 445-460.

5. Ashton, C., And Morton, L. (2005). Managing Talent For Competitive Advantage: Taking A Systemic Approach To Talent Management. Strategic $\mathrm{Hr}$ Review, 4(5), 28-31.

6. Barutçugil, İ. (2002), Performans Yönetimi (Performance Management), İstanbul: Kariyer Yayınları

7. Bhatnagar, J. (2007). Talent Management Strategy of Employee Engagement In Indian ITES Employees: Key To Retention. Employee Relations, 29(6), 640-663.

8. Cappelli, P. (2008). Talent Management For The Twenty-First Century. Harvard Business Review, 86(3), 74.

9. Çabukel, R. (2008), Çalışan Memnuniyeti Analizleri (Analyses of 
Employee Satisfaction), Unpublished Graduate Thesis, İstanbul: İstanbul Üniversitesi Sosyal Bilimler Enstitüsü.

10. Cappelli, P., \& Keller, J. R. (2014). Talent management: Conceptual approaches and practical challenges. Annu. Rev. Organ. Psychol. Organ. Behav., 1(1), 305-331.

11. Chi, C. G. and Gursoy, D. (2009).

Employee Satisfaction, Customer Satisfaction, And Financial Performance: An Empirical Examination. International Journal Of Hospitality Management, 28(2), 245-253.

12. Cohen, D, (2001), The Talent Edge: A Behavioral Approach To Hiring, Developing, And Keeping Top Performers, (Birinci Basım, Toronto: John Wiley\&Sons). 13. Collings, D. G. and Mellahi, K. (2009). Strategic Talent Management: A Review And Research Agenda.Human Resource Management Review, 19(4), 304-313.

14. Collings, D. G., Scullion, H. and Vaiman, V. (2015). Talent management: Progress and prospects.

15. Cronbach, L. J. (1951). Coefficient alpha and the internal structure of tests. psychometrika, 16(3), 297-334.

16. Dandridge, T. C., Mitroff, I. and Joyce, W. F. (1980), Organizational Symbolism: A Topic To Expand Organizational Analysis, Academy Of Management Review, 5, 77-82. 17. Doğan, S. and Demiral, Ö. (2008), "İnsan Kaynakları Yönetiminde Çalışanların Kendilerine Doğru Yolculuk Yöntemi: Yetenek Yönetimi" (Human Resource Management Journey Towards The Employees Themselves Method: Talent Management), Ç. Ü. Sosyal Bilimler Enstitüsü Dergisi, Cilt 17, Sayı 3, 145-166.

18. Erdemir, E. (2006) "Bilgi Toplumunda İnsan Kaynakları Yönetiminin Yeni Rolü: Yetenek Savaşları Olgusu Ve Türkiye'deki Yansimaları" (New Role Of Human Resource Management In The Information Society: A Case Of Turkey And Reflections
On Talent War), 5. Knowledge, Economy And Management Congress, 30- 39

19. Eren, E. (1996), Yönetim Psikolojisi (Psychology Of Management), Beta Basım Yayın, İstanbul.

20. Erken, M. (2013), “Çalışan Memnuniyeti Üzerine Sağlık Sektöründe Bir Araştırma" (A Study On Employee Satisfaction In The Health Sector), Unpublished Graduate Thesis, Marmara Üniversitesi Sosyal Bilimler Enstitüsü İşletme Anabilim Dalı, İstanbul.

21. Farley, C. (2005). Hr's Role In Talent Management And Driving Business Results. Employment Relations Today, 32(1), 55-61.

22. Gardner, R. C. (2002), Social Psychological Perspective On Second Language Acquisition, In Kaplan, R. B. (Ed. ). The Oxford Handbook of Applied Linguistics, New York: Oxford University Press.

23. Gilley, J. W., Eggland, S. A., and Gilley, A. M. (2002). Principles Of Human Resource Development. Basic Books.

24. Harter, J. K., Schmidt, F. L. and Hayes, T. L. (2002). Business-Unit-Level Relationship Between Employee Satisfaction, Employee Engagement, And Business Outcomes: A Meta-Analysis. Journal of Applied Psychology, 87(2), 268.

25. Heinen, J. , O’neill, C. (2004), “Managing Talent To Maximize Performance", Employment Relations Today, Volume: 31,No: 2.

26. Hair, J. F., Tatham, R. L., Anderson, R. E. and Black, W. (2006). Multivariate data analysis (Vol. 6). Upper Saddle River, NJ: Pearson Prentice Hall.

27. Kraiger, K., Ford, J. K. and Salas, E. (1993). Application of Cognitive, SkillBased, And Affective Theories Of Learning Outcomes To New Methods of Training Evaluation.Journal of Applied Psychology, 78(2), 311.

28. Lawler, E. E. (2000). Rewarding Excellence (Vol. 13). San Francisco: JosseyBass. 
29. Lewis, R. and Heckman, R. (2006), Talent Management: A Critical Review, Human Resource Management Review, 16. 30. Little, B. (2006), "The Sum of The Parts", E-Learning Age, Trends In Learning,24- 25.

31. Madlock, P. E. (2008). The Link Between Leadership Style, Communicator Competence, And Employee Satisfaction. Journal of Business Communication,45(1), 61-78.

32. Mellahi, K. and Collings, D. G. (2010). The Barriers To Effective Global Talent Management: The Example of Corporate Élites In Mnes. Journal of World Business, 45(2), 143-149.

33. Minbaeva, D. and Collings, D. G. (2013). Seven Myths of Global Talent Management. The International Journal of Human Resource Management,24(9), 17621776.

34. Mucha, R. T. (2004), "The Art And Science of Talent Management", Organization Development Journal, Vol. 22, No: 4, 96-100.

35. Murphy, M. , Lyons, G. and O'mahoney, G. (2005), Member of Deloitte Touche Tohmatsu, "If People Are Our Greatest Assets.", Management Brieffing - Employee Retention Strategies.

36. Nakip, M. , (2003), Pazarlama Araştırmaları Teknikler Ve (Spss Destekli) Uygulamalar (Marketing Research And Techniques (Spss Aided) Applications), Seçkin Yayıncılık, 1. Baskı, Ankara

37. Olian, J. D. and Rynes, L. (1984), "Organizational Staffing: Integrating Practice With Strategy", Industrial Relations, 23(2), 170-183

38. Özgen, H. , Öztürk, A. and Yalçin, A. (2005), İnsan Kaynakları Yönetimi (Human Resource Management), Nobel Kitabevi, Adana.

39. Pfeffer, J. (1981), "Management As Symbolic Action: The Creation And Maintenance Of Organizational Paradigms". L. L. Cummings Ve B. M. Staw (Eds. ),
Research In Organizational Behavior, Vol. 3, 152

40. Pekdemir, I. , Özçelik, O. , Karabulut, E. and Arslantaş, C. C. (2006) "Personel Güçlendirme, İş Tatmini Ve Örgütsel Bağlılık Arasındaki İlişkileri Belirlemeye Yönelik Bir Çalışma (A Study For Determining The Relationship Between Employee Empowerment, Job Satisfaction And Organizational Commitment)", Verimlilik Dergisi, 4, 11-36.

41. Pettit, J. D., Goris, J. R. and Vaught, B. C. (1997). An Examination Of Organizational Communication As A Moderator of The Relationship Between Job Performance And Job Satisfaction. Journal of Business Communication, 34(1), 81-98.

42. Polat, (2011), "Yetenek Yönetimi" (Talent Management) Ankara Sanayi Odası Yayını, Mayıs / Haziran 2011, 27-38.

43. Pynes, J. E. (2008). Human Resources Management For Public And Nonprofit Organizations: A Strategic Approach (Vol. 30). John Wiley \& Sons.

44. Schneider, B. (1983), "Interactional Psychology And Organizational Behavior", L. L. Cummings Ve B. M. Staw (Eds.), Research In Organizational Behavior, (Beşinci Basım, Greenwich, Ct: Jai Press).

45. Sims, R. L. and Kroeck, K. G. (1994). The Influence of Ethical Fit On Employee Satisfaction, Commitment And Turnover. Journal of Business Ethics, 13(12), 939-947.

46. Şimşek, M. (1998), Kalite Yönetimi (Total Quality Management), İstanbul, Alfa Basım.

47. Sparrow, P., Farndale, E. and Scullion, H. (2013). An Empirical Study Of The Role Of The Corporate Hr Function In Global Talent Management In Professional And Financial Service Firms In The Global Financial Crisis. The International Journal of Human Resource Management, 24(9), 1777-1798.

48. Storey, J. (1988). Developments In The Management of Human Resources. 
Management Research News,11(1/2), 27-

27.

49. Tarique, I. and Schuler, R. S. (2010). Global Talent Management: Literature Review, Integrative Framework, And Suggestions For Further Research. Journal of World Business, 45(2), 122-133.

50. Telman, N. and Ünsal, P. (2004), Çalışan Memnuniyeti (Employee Satisfaction), İstanbul, Epsilon Yayınevi.

51. Thunnissen, M., Boselie, P. and Fruytier, B. (2013). A Review Of Talent Management:'Infancy Or Adolescence?'. The International Journal of Human Resource Management, 24(9), 17441761.

52. Türkbal, A. (1981), Bilimsel Araştırma Metodları Ve Uygulamalı İstatistik (Scientific Research Methods And Applied Statistics), Erzurum.
53. Ulrich, D. (1998). A New Mandate For Human Resources. Harvard Business Review, 76, 124-135.

54. Yavan, Ö. (2012), "Yetenek Yönetimi" (Talent Management), Kamu-İş Dergisi, C:12, S:2/2012, 75-100.

55. Vaiman, V., Collings, D. G. and Scullion, H. (2017). Contextualising talent management. Journal of Organizational Effectiveness: People and Performance, 4(4), 294-297.

56. Wangenheim, F. V., Evanschitzky, H. and Wunderlich, M. (2007). Does The Employee-Customer Satisfaction Link Hold For All Employee Groups?.Journal of Business Research, 60(7), 690-697.

57. Yüksel, Ö. (2004), “İnsan Kaynakları Yönetimi” (Human Resource Management, Ed. Tülin Durukan, Girişimciler İçin İşletme Yönetimi, Gazi Kitabevi, Ankara, Bölüm 10, 339-383. 